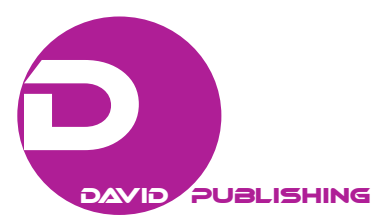

\title{
Additional Education and Training in Polish Agricultural Cooperatives
}

\author{
Małgorzata Matyja \\ Wrocław University of Economics, Wrocław, Poland
}

\begin{abstract}
Environmental conditions require, from companies and their employees, continuous learning and acquiring new knowledge, skills, and competences, which generally may be named as shaping the human capital. The same refers to agricultural cooperatives and more specifically their members and employees. The article describes the usage of one of cooperative principles, concerning education, training, and information, in Polish agricultural cooperatives. The purpose of the article is to describe the educational needs of members and employees of agricultural cooperatives. The article brings the answers for the following questions: What is the interest of additional education and professional development in Polish agricultural cooperatives? What are the areas of interest of education? What forms of education are appropriate? Who most needs education? The article utilizes the results of research conducted in 2013. The research method was a survey sent electronically to the managers of 1,147 cooperatives. Approximately 50 respondents took part in the research. Data analysis included the method of logical inference. The findings are disturbing. It turns out that the level of educational needs in Polish agricultural cooperatives is small. The reasons for this are most often the lack of funds, the lack of faith in ensuring tangible effects of training, and the general members' antipathy to make efforts to improve the knowledge and skills which results from their age close to retirement. The main conclusion is that this might have its source in the wider context of changes in Poland in general and associating Polish agricultural cooperatives with the forced collectivization of agriculture that is still observed, even by the cooperatives members themselves.
\end{abstract}

Keywords: agricultural cooperatives, cooperative members, human capital, educational needs, additional education, professional development

\section{Introduction}

Education is a basic human right and a significant factor in the development of children, communities, and countries. Across the developed world, everybody agrees about the importance of education (Wilkinson \& Pickett, 2009). It positively influences on society, which needs the contributions and economic productivity of a skilled workforce and simultaneously it is good for individuals.

The local and regional socio-economic development nowadays is indispensably connected with the improvement of human knowledge and skills both in individual and collective dimensions. This can be viewed as human capital shaping. In the era of building knowledge-based economy, the human need of learning takes on the special significance. It turns out that completing the education at school level becomes insufficient to

Małgorzata Matyja, Ph.D., Wrocław University of Economics, Wrocław, Poland.

Correspondence concerning this article should be addressed to Małgorzata Matyja, Wrocław University of Economics, Komandorska Street 118/120, 53-345 Wrocław, Poland. E-mail: malgorzata.matyja@ue.wroc.pl. 
function in today's world, especially in business conditions. Therefore, a man should participate in the vocational education and training also at the stage of adult life.

This fact refers also and maybe especially to members of agricultural cooperatives. One of several cooperative principles concerns education, training, and information (Oczkowski, Krivokapic-Skoko, \& Plummer, 2013). This means, more or less, that cooperatives should provide education and training for their members, elected representatives, managers, and employees.

The article somehow describes the usage of the mentioned cooperative principle in practice of Polish agricultural cooperatives. Precisely, the purpose of this article is to describe the educational needs of members and employees of agricultural cooperatives in Poland. This issue seems to have the particular importance for the Polish cooperatives. They still suffer from the negative perception of the environment as a relic of the previous political system and often face a number of internal problems (Dzun, 2009; Chloupková, 2002). Maybe a bit of additional education and concern about professional development would help them to adapt to the changing world.

\section{Literature Review}

The importance of agricultural extension and education seems to be essential (Solouki, Allahyari, \& Bordbar, 2011). With little or no access to education, the members are lacking the ability to participate meaningfully in cooperatives (Münkner, 2012). Education of cooperative members is essential to effective communications both internal and external to the co-op (Williamson, 1998). It refers to all areas of cooperatives activity, for example, Birchall (1997) claimed that one of the factors contributing to an enduring agricultural sector in America was the development of extension programmes by agricultural universities, some of which were to set up specialised co-operative education and training centres. In the same study, he also indicated three distinct phases in the history of cooperative education: firstly, providing basic literacy and technical education to members; secondly, in the environment of widespread state education - educating members about cooperative principles with formal qualifications through cooperative colleges; and lastly, providing less formal education and using new approaches. He specified that the third phase includes the following features:

- making sure that the right people are trained;

- providing training locally rather than in colleges abroad;

- making courses relevant to the problems of local cooperatives;

- linking training to the work situation;

- active participation by students;

- networking with participants after training has ended;

- promoting sustainability by building the capacity of local training agencies;

- educating the general public about cooperatives.

Robb (2011) identified the importance of participating in on-going education for and about cooperatives and determined the diversity of needs of people within and outside cooperatives. He warned about the consequences of trivializing the role of education in cooperatives, quoting Schildgen (1989) as saying that in case after case, when a coop has gone under, observers have cited the decline of cooperative education as a major factor in the failure.

In the context of such important role of education in cooperatives, this study describes the approach to this issue on the example of Polish agricultural cooperatives. 


\section{Research Methods}

In Poland, agricultural cooperatives perform the functions of production, service, and processing related to agriculture. This includes mainly supply and sales co-operatives, dairy co-operatives, gardening and apicultural co-operatives, co-operatives of agricultural organizations, and agricultural production co-operatives, which are described in Table 1 .

Table 1

Basic Statistical Data on Polish Agricultural Cooperatives (Outstanding at 2011)

\begin{tabular}{|c|c|c|c|c|}
\hline Type of cooperative & Field of activity & $\begin{array}{l}\text { Number of active } \\
\text { co-operatives }\end{array}$ & $\begin{array}{l}\text { Estimated number } \\
\text { of members }\end{array}$ & $\begin{array}{l}\text { Estimated number } \\
\text { of workers }\end{array}$ \\
\hline $\begin{array}{l}\text { Supply and sales cooperatives } \\
\text { "Samopomoc Chłopska" }\end{array}$ & $\begin{array}{l}\text { Trade, services for agriculture, food } \\
\text { processing, and production }\end{array}$ & 1,259 & 200,000 & 85,000 \\
\hline Dairy cooperatives & $\begin{array}{l}\text { Purchase of agricultural raw } \\
\text { materials and food production } \\
\text { (milk and milk products) }\end{array}$ & 156 & 150,000 & 18,000 \\
\hline $\begin{array}{l}\text { Gardening and apicultural } \\
\text { cooperatives }\end{array}$ & $\begin{array}{l}\text { Food production } \\
\text { (fruits, vegetables, and honey) }\end{array}$ & 73 & 10,000 & 2,000 \\
\hline $\begin{array}{l}\text { Cooperatives of agricultural } \\
\text { organizations }\end{array}$ & Services for agriculture & 570 & na & 10,000 \\
\hline $\begin{array}{l}\text { Agricultural production } \\
\text { cooperatives }\end{array}$ & $\begin{array}{l}\text { Agricultural production } \\
\text { (crops and livestock farming) }\end{array}$ & 734 & $42,000 *$ & $8,000^{*}$ \\
\hline $\begin{array}{l}\text { Cooperative agricultural } \\
\text { producers group }\end{array}$ & $\begin{array}{l}\text { Agricultural production } \\
\text { (crops and livestock farming) }\end{array}$ & 192 & na & na \\
\hline Total & & 2,984 & - & - \\
\hline
\end{tabular}

Notes. * means data in 2013; na means data non available. Source: Boguta (2011) and National Council of Cooperatives (2013).

The empirical research on the educational needs of agricultural cooperatives was conducted in 2013 using a questionnaire, which was sent electronically to the managers of 1,147 cooperatives. They were asked to give the response to a set of 17 closed questions. Only 48 respondents filled out the questionnaire, which means that the total rate of responses' return is approximately $4 \%$. Most of the surveys were filled out by representatives of agricultural production cooperatives. Ten percent of these enterprises took part in the survey.

\section{Research Results}

The respondents' answer to the basic question of the interest of additional education and professional development in Polish agricultural cooperatives might sound a bit surprising (Table 2, issue 1). It turns out that almost $70 \%$ of cooperative members are not interested at all or have only little interest in additional education and professional development. Only $2 \%$ admitted that this interest was strong. Thus, in general, the educational needs seem to have no significance in agricultural cooperatives.

The next question that arises is about the reasons for this phenomenon. The answers are shown in Table 3 . Members of agricultural cooperatives are at the most the elderly people who claim that they do not need to learn anymore and simply want to wait for the upcoming retirement. This was said by $21 \%$ of respondents. Not much less, it means that exactly $20 \%$ admitted that they did not believe in real tangible results of training or studies, which in this context they treat like a waste of time. The barriers in further education for the $17 \%$ of respondents are also the lack of funds and time. People of $13 \%$ see themselves as someone who know and can do everything in their work, so they do not need additional education. People of $11 \%$ complain about the lack of appropriate training offer and $2 \%$ are afraid to return to "school". No other reasons were indicated. 
Table 2

The Research Results on Basic Issues Concerning Educational Needs in Polish Agricultural Cooperatives

\begin{tabular}{|c|c|c|c|}
\hline \multirow{3}{*}{ Issue } & 1 & 2 & 3 \\
\hline & $\begin{array}{l}\text { The cooperative members' interest of } \\
\text { additional education and professional } \\
\text { development }\end{array}$ & $\begin{array}{l}\text { The respondents' possibilities and } \\
\text { willingness to send their subordinates } \\
\text { to studies }\end{array}$ & $\begin{array}{l}\text { The respondents' possibilities and } \\
\text { willingness to send their subordinates } \\
\text { to training or courses }\end{array}$ \\
\hline & \multicolumn{3}{|c|}{ Percentage of responses } \\
\hline None & $25 \%$ & $60 \%$ & $13 \%$ \\
\hline Little & $44 \%$ & $17 \%$ & $35 \%$ \\
\hline Average & $29 \%$ & $13 \%$ & $28 \%$ \\
\hline Strong & $2 \%$ & $10 \%$ & $22 \%$ \\
\hline Very strong & $0 \%$ & $0 \%$ & $2 \%$ \\
\hline
\end{tabular}

Table 3

The Reasons of Very Little Interest of Additional Education and Professional Development in Cooperatives

\begin{tabular}{lcc}
\hline Reason & No. of responses & Percentage \\
\hline Attitude of members expressed in the statement: "I do not need it, I calmly wait for retirement" & 20 & $21 \%$ \\
Lack of faith that additional training or studies can bring tangible results & 19 & $20 \%$ \\
Lack of funds & 16 & $17 \%$ \\
Lack of time & 16 & $17 \%$ \\
Attitude of members expressed in the statement: "I do not need it, I know and can do everything" & 12 & $13 \%$ \\
Lack of appropriate training offer & 10 & $11 \%$ \\
Lack of confidence, fear of return into "school benches" & 2 & $2 \%$ \\
\hline
\end{tabular}

The cooperative managers were also asked what such training offer should include. Table 4 presents which type of trainings would and would not meet with cooperative's educational needs. Opinions were divided. People of $40 \%$ claim that there is no or very little demand for specialist courses (such as cultivation of plants, zootechnics, or the use of agricultural vehicles), whilst 33\% see this demand as very strong or strong. People of $46 \%$ would rather not go to the training about financial support instruments for agriculture, but $33 \%$ would rather choose this. People of $44 \%$ would like to learn how to obtain EU funds, but $33 \%$ are not interested in this subject. What can certainly be said is that the majority of respondents do not need trainings on agrotourism and rural tourism (91\% of responses), the creation of producer groups (78\% of responses), and ecological agriculture ( $74 \%$ of responses).

The respondents also indicated in which form such education should be organized (Table 5). They claim that for the cooperatives members, it should be mainly trainings or courses in or outside the workplace. They are definitely not interested in e-learning forms or studies at the university.

The responses for the second issue in Table 2 also confirmed these conclusions. People of $77 \%$ (in total) of cooperatives managers do not want or have the possibility to send their subordinates (members and employees) to studies. Only $10 \%$ declare their willingness to enable their subordinates to use this educational opportunity.

However, the managers' willingness to send employees to different trainings or courses is higher. This is presented also in Table 2 (issue 3). Almost one fourth want their subordinates to take the advantage of this form of education. Approximately half (48\% in total) do not see such need.

The group in agricultural cooperatives which needs additional education and professional development the most is managerial staff. In total, $73 \%$ of respondents very strongly, strongly, or on average recommend 
trainings for this group. Approximately a half claimed that further education would be useful also for administrative staff and for workers. The vast majority do not see the educational need for the candidates for the member of the cooperative. These research results are shown in Table 6.

Table 4

The Degree of the Demand for Different Types of Trainings for Cooperative Members

\begin{tabular}{|c|c|c|c|c|c|}
\hline Type of training & None & Little & Average & Strong & Very strong \\
\hline Specialist courses & $13 \%$ & $27 \%$ & $27 \%$ & $27 \%$ & $6 \%$ \\
\hline Accounting and taxes & $26 \%$ & $28 \%$ & $21 \%$ & $19 \%$ & $6 \%$ \\
\hline Management of cooperative & $26 \%$ & $28 \%$ & $21 \%$ & $19 \%$ & $6 \%$ \\
\hline Entrepreneurial & $35 \%$ & $17 \%$ & $26 \%$ & $20 \%$ & $2 \%$ \\
\hline Creation of producer groups & $48 \%$ & $30 \%$ & $15 \%$ & $4 \%$ & $2 \%$ \\
\hline Financial support instruments for agriculture & $23 \%$ & $23 \%$ & $21 \%$ & $27 \%$ & $6 \%$ \\
\hline Obtaining EU funds & $13 \%$ & $21 \%$ & $23 \%$ & $33 \%$ & $10 \%$ \\
\hline Ecological agriculture & $50 \%$ & $24 \%$ & $17 \%$ & $9 \%$ & $0 \%$ \\
\hline Modern technologies of agricultural production & $30 \%$ & $13 \%$ & $26 \%$ & $20 \%$ & $11 \%$ \\
\hline Agritourism and rural tourism & $76 \%$ & $16 \%$ & $4 \%$ & $4 \%$ & $0 \%$ \\
\hline
\end{tabular}

Table 5

The Degree of the Demand for Different Forms of Trainings for Cooperative Members

\begin{tabular}{lccccc}
\hline Form of training & None & Little & Average & Strong & Very strong \\
\hline Training and courses in the workplace & $13 \%$ & $26 \%$ & $45 \%$ & $15 \%$ & $2 \%$ \\
Training and courses outside the workplace & $20 \%$ & $37 \%$ & $30 \%$ & $11 \%$ & $2 \%$ \\
E-learning training and courses & $69 \%$ & $18 \%$ & $7 \%$ & $7 \%$ & $0 \%$ \\
Postgraduate studies at the university & $71 \%$ & $18 \%$ & $11 \%$ & $0 \%$ & $0 \%$ \\
\hline
\end{tabular}

Table 6

The Degree of the Demand for Additional Education According to Different Groups in Cooperatives

\begin{tabular}{lccccc}
\hline Group & None & Little & Average & Strong & Very strong \\
\hline Managerial staff & $4 \%$ & $23 \%$ & $46 \%$ & $23 \%$ & $4 \%$ \\
Workers & $15 \%$ & $36 \%$ & $32 \%$ & $17 \%$ & $0 \%$ \\
Administrative staff & $15 \%$ & $36 \%$ & $32 \%$ & $17 \%$ & $0 \%$ \\
Candidates for members of the cooperative & $66 \%$ & $19 \%$ & $9 \%$ & $6 \%$ & $0 \%$ \\
\hline
\end{tabular}

\section{Discussion}

Summing up, the educational needs in cooperatives are not in the high level. This might have its source in the wider context of changes in Poland in general. After the Second World War, the communist system determined the political, economic, and social life of the whole country for a long time. The agricultural cooperatives, initially organized spontaneously, mainly by former employees of the manor and the farmers themselves (Bajan, 1988), become a tool in the hands of contemporary authorities to achieve its political, economic, and social objectives.

A serious blow to the agricultural cooperatives was caused by the political transformation in Poland in the early 1990s (Matyja, 2012). Now, after 25 years of transformation, structural change in agriculture is slowing down, as a result of EU Common Agricultural and National Policies (Kozak, 2014). The agrarian structure is dominated by subsistence farms with the average farm size below 10 hectares. As a result, rural areas are still in need of deep restructuring and the modernization of economic structures. But individual farmers do not rather 
want to act together in cooperative form. Unfortunately, agricultural cooperatives are still associated with the forced collectivization of agriculture and therefore perceived as a product of the previous system (Dzun, 2009), even by the cooperatives members themselves. It seems to be one of the main problems faced by cooperatives in rural areas. The next ones, such as unwillingness to realize educational needs, may be a consequence of it.

\section{Conclusions}

The findings shown in this article are disturbing. It turns out that the level of interest and demand for courses and training in Polish agricultural cooperatives is small. The reasons for this is most often the lack of funds, the lack of faith in ensuring tangible effects of training and the general members' antipathy to make efforts to improve the knowledge and skills which results from their age close to retirement. The next author's research (not mentioned in this article) at the same sample showed that the cooperative members are optimistic about the future of their cooperatives and do not complain about the achieved earnings. In the context of the requirements, a knowledge-based economy on one hand and the lack of interest in improving knowledge and skills in cooperatives on the other, this optimism, unfortunately, seems to be unfounded.

\section{References}

Bajan, K. (1988). Some problems of agricultural productive cooperativeness. Proceedings from the Scientific Conference of Institute of Agricultural and Food Economics and Central Association of Agricultural Productive Cooperatives.

Birchall, J. (1997). The international co-operative movement. Manchester: Manchester University Press.

Boguta, W. (2011). Rural cooperatives as one of the main forms of joint economic activities of people. Warsaw: National Council of Cooperatives.

Chloupková, J. (2002). European cooperative movement-Background and common denominators (Unit of Economic Working Papers, The Royal Veterinary and Agricultural University, Copenhagen, Denmark).

Dzun, W. (2009). Co-operatives of agricultural production in the process of systemic change. Agricultural Economics Issues, 4 , 74-87.

Kozak, M. W. (2014). The transformation of Polish rural areas since 1989. Wieś i Rolnictwo, 1, 155.

Matyja, M. (2012). Economic and social importance of agricultural productive cooperatives in Poland. Journal of Agribusiness and Rural Development, 4(26), 60-61.

Münkner, H. H. (2012). Co-operation as a remedy in times of crisis. Agricultural co-operatives in the world. Their roles for rural development and poverty reduction. Marburg Studies on Cooperation and Cooperatives, 58, 26.

National Council of Cooperatives. (2013). Data on agricultural production cooperatives. Retrieved from http://www.krs.org.pl/index.php?option=com_content\&view=article\&id=30\&Itemid=286

Oczkowski, E., Krivokapic-Skoko, B., \& Plummer, K. (2013). The meaning, importance and practice of the co-operative principles: Qualitative evidence from the Australian co-operative sector. Journal of Co-operative Organization and Management, 1, 54.

Robb, A. J. (2011). Cooperative education. Halifax: Saint Mary's University.

Schildgen, B. (1989). Co-op education is about co-operatives. Retrieved from http://www.cooperativegrocer.coop/articles/index.php?id=65

Solouki, M., Allahyari, M. S., \& Bordbar, M. (2011). Analysis of effective factors to increase the knowledge of agricultural production cooperative members in Semnan Province, Iran. African Journal of Agricultural Research, 6(32), 6648.

Wilkinson, R., \& Pickett, K. (2009). The spirit level. Why equality is better for everyone. London: Penguin.

Williamson, L. (1998). Cooperative education and communication. Lexington: University of Kentucky College of Agriculture. 